\title{
Peningkatan Kemampuan Motorik Halus Anak Usia 5-6 Tahun Melalui Penggunaan Play Dough
}

\author{
Sumardi ${ }^{1}$, Lutfi Nur ${ }^{2}$, Peny Angraeni ${ }^{3}$ \\ ${ }^{1}$ Program Studi PGPAUD UPI Kampus Tasikmalaya \\ ${ }^{2}$ Program Studi PGPAUD UPI Kampus Tasikmalaya \\ ${ }^{3}$ Program Studi PGPAUD UPI Kampus Tasikmalaya
}

Email: sumardipgpaud@gmail.com

(Received: Mei 2018; Accepted: Mei 2018; Published: Juni 2018)

\begin{abstract}
Early childhood is laying the foundation for growth and development is crucial for the child in the future. To be able to support that teachers should provide a wide range of strategies to achieve the expected competencies based on standard achievement level child development (STPPA). The scope of development listed in STPPA among which the religious and moral values, physical, motor, cognitive, language, social, emotional and artistic. Based on observations conducted in children aged 5-6 years group B TK Sejahtera 4 motor ability in the physical aspects of the scope of the development of fine motor skills are still low, especially related to the children imitate the skills varied line, cutting, writing letters of the alphabet and learning hijaiyah this is due to improve fine motor skills is not optimal and does not vary. Researchers hope that by using the right learning media can improve fine motor development and can improve learning outcomes are optimal. To the researchers undergo a learning improvement through action research methods class (PTK) developed by Kemmis McTaggart. Through play dough (play dough) kneading child, print and form. Through the experience of children practicing coordinate eye and hand control, agility and strength are important capabilities that they will need later to write. The results of the study in the first cycle there are 4 children in underdeveloped and 16 children began to grow with the overall percentage of the first cycle of $46 \%$ and the number of children who attended as many as 20 children, in the second cycle are 9 children begin to develop and 8 children to develop according expectations with the overall percentage of $63 \%$ as well as the number of children who attended were 17 children and the third cycle, there were 13 children develop according to expectations and 4 children is growing very well with the overall percentage of $84 \%$ as well as the number of children who attended as many as 17 children. This shows an increase in the fine motor skills of children aged 5-6 years through the use of play dough in group B TK Sejahtera 4 Karsamenak, Kawalu, Tasikmalaya in the academic year 2016-2017.
\end{abstract}

Keywords: Fine motor skills, Play Dough, Children Aged 5-6 Years

\begin{abstract}
ABSTRAK
Pendidikan anak usia dini merupakan penyelenggaraan pendidikan yang menik beratkan pada pertumbuhan dan perkembangan, sedangkan usia dini merupakan peletakkan dasar bagi pertumbuhan dan perkembangan yang sangat menentukan bagi anak di masa depannya. Untuk dapat mendukung hal tersebut guru harus menyediakan berbagai macam strategi guna tercapainya kompetensi yang diharapkan berdasarkan standar tingkat pencapaian perkembangan anak (STPPA). Lingkupnya yaitu nilai agama dan moral, fisik motorik, kognitif, bahasa, sosial emosional dan seni. Berdasarkan hasil observasi yang dilakukan pada anak usia 5-6 tahun kelompok B TK Sejahtera 4 kemampuan dalam aspek fisik motorik lingkup perkembangan motorik halusnya masih rendah terutama yang berhubungan dengan keterampilan anak meniru garis bervariasi, menggunting, menulis huruf abjad dan hijaiyah hal ini disebabkan pembelajaran untuk meningkatkan kemampuan motorik halus belum optimal dan tidak bervariasi. Peneliti berharap media ini dapat meningkatkan perkembangan motorik halus. Untuk itu peneliti melakuan perbaikan pembelajaran melalui metode penelitian tindakan kelas (PTK) yang dikembangkan oleh Kemmis McTaggart. Melalui bermain adonan (play dough) anak meremas, mencetak dan membentuk. Lewat pengalaman tersebut anak berlatih mengkoordinasikan mata dan tangan yang terkontrol, ketangkasan dan kekuatan merupakan kemampuan penting yang mereka akan butuhkan kelak untuk menulis. Hasil penelitian pada siklus I terdapat 4 orang anak belum berkembang dan 16 orang anak mulai berkembang dengan persentase keseluruhan siklus I sebesar $46 \%$ serta jumlah anak yang hadir sebanyak 20 orang anak, pada siklus II terdapat 9 orang anak mulai berkembang dan 8 orang anak berkembang sesuai harapan dengan persentase keseluruhan $63 \%$ serta jumlah anak yang hadir sebanyak 17 orang anak dan siklus III terdapat 13 orang anak berkembang sesuai harapan dan 4 orang anak berkembang sangat baik dengan persentase keseluruhan $84 \%$ serta jumlah anak yang hadir sebanyak 17 orang anak. Hal ini menunjukkan adanya peningkatan kemampuan motorik halus anak usia 5-6 tahun melalui penggunaan play dough pada kelompok B TK Sejahtera 4 Kelurahan Karsamenak Kecamatan Kawalu Kota Tasikmalaya Tahun Pelajaran 2016-2017.
\end{abstract}

Kata kunci : Motorik Halus, Play Dough, Anak Usia 5-6 Tahun 


\section{PENDAHULUAN}

Pendidikan anak usia dini merupakan suatu jenjang pendidikan untuk anak sejak lahir sampai dengan usia enam tahun. Kemudian di tegaskan kembali oleh Sujiono (2009, hlm. 6) bahwa "pendidikan anak usia dini merupakan salah satu bentuk penyelenggaraan pendidikan yang menitikberatkan pada peletakan dasar ke arah pertumbuhan dan perkembangan". Perkembangan tersebut meliputi perkembangan fisik motorik, kognitif, sosio emosional serta bahasa, dimana setiap anak memiliki keunikan yang berbeda-beda.

Dalam peraturan menteri pendidikan dan kebudayaan republik indonesia nomor 137 tahun 2014 tentang standar nasional pendidikan anak usia dini, terdapat tingkat pencapaian perkembangan anak pada halaman 21 lampiran 1. Tingkat pencapaian perkembangan anak tersebut tercapai seiring pembelajaran berlangsung, agar tahap perkembangan tercapai secara optimal maka pembelajaran harus disuguhkan dengan optimal pula salah satunya dengan memperhatikan media pembeajaran yang digunakan.

Mengingat pentingnya media dalam proses pembelajaran maka penggunaan media pembelajaran yang paling cocok untuk anak usia dini adalah bermain sambil belajar. Karna dunia anak adalah bermain, dengan bermain anak belajar melalui pengalaman yang didapatnya. Setiap anak mempunyai keunikan masing-masing sehingga tidak bisa di samakan kemampuannya, antara satu anak dengan yang lainnya, mereka mempuyai tahapan-tahapan perkembangan yang berbeda-beda. Guru dituntut untuk bisa membedakan perbedaan itu, sehingga dibutuhkan bekal yang cukup untuk menghadapinya. Banyak permasalahan yang ditemukan didalam menghadapi anak-anak tersebut baik dari segi kemampuannya, salah satunya adalah dalam aspek perkembangan motorik halusnya.

Play dough atau bermain adonan merupakan material lunak, bisa diremas dan mudah dicetak. Menurut Swarts (dalam Beaty, 2015, hlm. 253) "adonan mainan memungkinkan anak-anak melatih kemampuan motorik halus".

Berdasarkan hasil observasi yang telah dilakukan oleh peneliti permasalahan yang terjadi di kelompok B TK Sejahtera 4 Kelurahan Karsamenak Kota Tasikmalaya, yaitu kurangnya antusias anak dalam mengikuti pembelajaran, rendahnya kemampuan perkembangan motorik halus anak terutama yang berhubungan dengan keterampilan seperti meniru garis bervariasi, menggunting, menulis huruf abjad dan hijaiyah, kemudian pembelajaran untuk meningkatkan perkembangan motorik halus yang di lakukan guru masih belum optimal dan tidak bervariasi.

Hal ini disebabkan oleh penggunaan media pembelajaran yang digunakan belum tepat, hasil pembelajarn yang telah dilaksanakan oleh guru terkadang tidak sesuai dengan harapan. Keberhasilan pembelajaran dapat dilihat dari ketercapaian kompetensi dasar dan indikator yang telah ditetapkan dalam kurikulum.

Dengan menggunakan media pembelajaran yang tepat diharapkan dapat meningkatkan perkembangan motorik halus dan bisa meningkatkan hasil belajar yang optimal. Untuk itu peneliti melakuan perbaikan pembelajaran melalui penenlitian tindakan kelas (PTK).

Mulyasa (2013, hlm. 11) mengatakan bahwa "penelitian tindakan kelas (PTK) adalah suatu upaya untuk mencermati kegiatan belajar sekelompok peserta didik dengan memberikan sebuah tindakan (treatment) yang sengaja di munculkan." Dengan demikian hal ini dapat dirasakan secara langsung manfaat untuk meningkatkan dan memperbaiki kualitas pembelajaran di dalam kelas, melalui penelitian tindakan kelas (PTK) guru sedang melakukan refleksi terhadap dirinya sendiri dan permasalahan-permasalahan yang diteliti merupakan permasalahan-permasalahan yang dialami guru itu sendiri sehingga guru dapat mempraktikan secara langsung dengan teori yang sudah di dapatkan.

Berdasarkan latar belakang masalah di diatas, peneliti tertarik untuk melakukan 
penenlitian tindakan kelas (PTK) dengan judul "Peningkatkan Kemampuan Motorik Halus Anak Usia 5-6 Tahun melalui penggunaan Play Dough: (Penelitian Tindakan Kelas pada Kelompok B TK Sejahtera 4 Kelurahan Karsamenak Kecamatan Kawalu Kota Tasikmalaya Tahun Pelajaran 2016-2017)”.

Rumusan berikut merupakan masalah yang dijadikan fokus dari penelitian dan dapat diuraikan sebagai berikut:

1. Bagaimana perencanaan pembelajaran melalui penggunaan Play Dough dalam meningkatan kemampuan motorik halus pada anak di kelompok B TK Sejahtera 4 ?

2. Bagaimana proses pembelajaran melalui penggunaan Play Dough dalam meningkatan kemampuan motorik halus pada anak di kelompok B TK Sejahtera 4 ?

3. Bagaimana hasil kemampuan motorik halus pada anak di kelompok B TK Sejahtera 4 setelah di terapkannya penggunaan Play Dough?

\section{TINJAUAN PUSTAKA}

\subsection{Hakikat Pembelajaran di TK}

Menurut Sujiono (2009, hlm. 6) pendidikan anak usia dini merupakan "salah satu bentuk penyelenggaraan pendidikan yang menitik beratkan pada peletakkan dasar ke arah pertumbuhan dan perkembangan". Setiap anak selalu ingin bermain. Bermain merupakan sesuatu yang menyenangkan. Dunia anak adalah dunia bermain. Dengan bermain anak belajar, artinya anak yang berlajar adalah anak yang bermain dan anak yang bermain adalah anak yang belajar, hal ini dapat menstimulus anak untuk bereksplorasi dengan menggunakan benda-benda yang ada di sekitarnyanya, sehingga anak menemukan pengetahuan itu sendiri. Hal ini sejalan dengan apa yang telah dijelaskan oleh Piaget (dalam Gudemmi, 1990, hlm. 39) "all children should play. Play is the child's work. Play is the central model of learning for all young children." Yang artinya semua anak harus bermain. Bermain bagaikan pekerjaan bagi anak. Bermain merupakan model pembelajaran untuk anak.
Menurut Mukhtar,dkk (2013, hlm. 78) "bermain dapat dilakukan dengan tiga cara yaitu atas inisiatif anak, atas keputusan anak dan dengan dukungan guru atau orang dewasa". Untuk dapat mendukung anak bereksplorasi dengan benda-benda yang ada di sekitarnya, guru atau orang dewasa harus menyediakan berbagai macam cara untuk mendukung pengalaman anak. Menurut Soemiarti (dalam Yus 2010, hlm. 35) mengemukakan bahwa "kurikulum adalah seluruh usaha atau kegiatan sekolah untuk merangsang anak supaya belajar dalam rangka pengembangan seluruh aspek yang ada pada dirinya baik di dalam maupun di luar kelas serta lingkungannya". Kegiatan-kegiatan tersebut menurut Vygotsky (dalam Mukhtar dkk 2013, hlm. 82) terbagi menjadi empat pijakan yaitu:

“a. Pijakan lingkungan main, b. Pijakan awal main atau pijakan pengalaman sebelum main,

c. Pijakan saat main, d. Pijakan pengalaman setelah main (Recalling)."

Kompetensi yang harus di capai oleh anak terdapat pada Lampiran 1 Peraturan Menteri Pendidikan dan Kebudayaan Republik Indonesia nomor 137 tahun 2014 tentang Standar Nasional Pendidikan Anak Usia Dini, yang isinya berupa standar tingkat pencapaian perkembangan anak (STPPA). Dalam standar tingkat pencapaian perkembangan (STPPA) kompetensi dibedakan menjadi kompetensi inti (KI) dan kompetensi dasar (KD). Menurut Peraturan Menteri Pendidikan dan Kebudayaan Republik Indonesia nomor 146 tahun 2014 "kompetensi inti kurikulum 2013 pendidikan anak usia dini merupakan gambaran pencapaian standar tingkat pencapaian perkembangan anak pada akhir layanan paud 6 (enam) tahun.".

Menurut Indrati dkk (2014, hlm. 16) karakteristik cara belajar anak usia dini yaitu:

“1) Anak belajar secara bertahap. 2) Cara berpikir anak bersifat khas, 3) Anak-anak belajar dengan berbagai cara, 4) Anak belajar satu sama lain dalam lingkungan sosial, 5) Anak belajar melalui bermain." 
Menurut Indrati dkk (2014, hlm. 30) jenis-jenis metode pembelajaran tersebut yaitu:

“a) Metode bercerita, b) Metode demonstrasi, c) Metode bercakap-cakap, d) Metode pemberian tugas, e) Metode sosio drama atau bermain peran, f) Metode karyawisata, g) Metode karyawisata, h) Metode eksperimen."

Model pembelajaran merupakan suatu rancangan pembelajaran yang menggambarkan situasi proses pembelajaran, menurut Sujiono (2009, hlm. 140) penerapan model pembelajaran terbagi menjadi dua yaitu:

“(1) Model pembelajaran yang berpusat pada anak, (2) Model pembelajaran yang berpusat pada guru."

\subsection{Perkembangan Fisik Motorik pada Anak Usia Dini}

Menurut Wiyani (2014, hlm. 35) perkembangan fisik motorik anak usia dini dapat diartikan sebagai perubahan bentuk tubuh yang berpengaruh terhadap keterampilan gerak tubuhnya. Menurut Sugiyanto (2000, hlm. 3.8) sifat-sifat perkembangan kemampuan fisik anak usia dini dapat di identifikasi sebagai berikut:

“1) Terjadi perkembangan otot-oto besar yang cukup cepat pada usia dua tahun terakhir dimasa

anak-anak, 2) Berkembangnya otot-otot besar berpengaruh pada kekuatan yang cukup cepat,

3) Pertumbuhan kaki dan tangan yang proposional lebih cepat dibandingkan pertumbuhan bagian tubuh lainnya, 4) Terjadi peningkatan koordinasi gerak dan keseimbangan tubuhyang cukup cepat, 5) Meningatnya kemungkinan dan kesempatan melakukan berbagai macam aktivitas gerak fisik."

Menurut umama (2016, hlm. 9) motorik merupakan proses kemampuan gerak seorang anak. Hal ini sejalan dengan apa yang dijelaskan oleh Rahyubi (2011, hlm. 209) gerakan motorik adalah "suatu istilah yang digunakan untuk menggambarkan perilaku gerakan yang dilakukan oleh tubuh manusia". Akan tetapi tidak jarang terdapat beberapa ganggunan pada masa kanak-kanak yang mengakibatkan keterlambatan atau gangguan motoriknya yang disebabkan oleh individu itu sendiri dalam hal ini faktor internal yaitu gen. Seperti yang dikemukakan oleh Kurtz,L.A (2008, hlm.19) ".....cerebral palsy is a condition occurring in very early childhood that involves damage to the parts of the brain that influence muscle tone and that control movement." Seperti yang dijelaskan oleh Hoerr, T.R. (2010, hlm. 80) bahwa "Students don't need to be shown how to move; they just need to be allowed to do so. They need you to give them the opportunities, perhaps a little guidance, and a sincere affi rmation of their efforts...." Adapun fungsi pengembangan fisik motorik di taman kanak-kanak menurut Mudjito (2007, hlm. 2) yaitu:

“1) Melatih kelenturan dan mengkoordinasi otot-otot jari dan tangan, 2) Memacu pertumbuhan dan pengembangan fisik motorik, rohani dan kesehatan anak, 3) Membentuk, membangun

dan memperkuat tubuh anak, 4) Melatih keterampilan dan ketangkasan gerak dan berfikir

anak, 5) Meningkatkan perkembangan emosional anak, 6) Meningkatkan perkembangan

sosial anak, 7) Menumbuhkan perasaan menyenangi dan memahami manfaat kesehatan pribadi."

Menurut Rahyubi (2011, hlm. 222) jenis-jenis motorik terbagi menjadi dua yaitu motorik kasar (gross motor) dan motorik halus (fine motor). motorik halus menurut Iskandar (2005, hlm. 13) adalah bagian dari aktivitas atau keterampilan otot-otot kecil, seperti jarijari, tangan, lengan dan sering membutuhkan kecermatan dan koordinasi mata dan tangan. Keterampilan motorik halus tersebut diantaranya yaitu menggenggam, memegang, merobaek, menggunting, melipat, mewarnai, menggambar, menulis, dan menumpuk mainan. Wiyani (2014, hlm. 37). Dalam buku pedoman pembelajaran bidang pengembangan fisik/motorik di taman kanak-kanak (2007, hlm. 6) karakteristik perkembangan yang 
berhubungan dengan motorik halus, antara lain:

a) Dapat mengoles mentega pada roti; b)Dapat mengikat tali sepatu sendiri dengan sedikit

bantuan; c) Dapat membentuk dengan menggunakan tanah liat atau plastisin; d)Membangun menara yang terdiri dari 5-9 balok; e) Memegang ketas dengan satu tangan dan mengguntingnnya; f) Menggambar kepala dan wajah tanpa badan; g) Meniru melipat kertas satudua kali lipatan; h) Mewarnai gambar sesukanya; i) Memegang krayon atau pensil yang berdiameter lebar.

Adapun kegiatan-kegiatan lain yang dapat menstimulus kemampuan motorik halus anak menurut Wiratni (2016, hlm. 3) yaitu melalui “.....menjiplak bentuk, melipat kertas, meronce, menganyam, mencocok, menggunting, merobek, menggambar, mewarnai, membentuk dan menjahit." Menurut Putri (2016, hlm. 3) "Kemampuan motorik halus anak harus dilatih setiap hari dengan hal yang menyenangkan serta disukai anakanak.". Maka dapat simpulkan bahwa untuk meningkatkan kemampuan perkembangan fisik motorik dalam lingkup perkembangan motorik halus anak, guru maupun orang tua harus menstimulus melalui berbagai kegiatan dan menyenangkan yang dikuasai oleh anak serta sesuai dengan tahap perkembangan anak. "Anak yang memiliki keterampilan motorik yang baik akan lebih mudah menyesuaikan diri pada lingkungan sekitar'(Suciati dkk, 2016, hlm. 2).

\subsection{Media Pembelajaran di TK}

Media pembelajaran merupakan suatu perantara atau alat yang digunakan untuk menyampaikan pesan. Hal ini ditegaskan kembali oleh Gerlach dan Ely (dalam Mursyid, 2015, hml. 40) "media apabila di pahami secara garis besar adalah manusia, materi atau kejadian yang membangun kondisi yang membuat siswa mampu memperoleh pengetahuan, keterampilan atau sikap.”. Menurut Mursyad (2015, hlm 41) lingkungan belajar tersebut mencakup tujuan pembelajaran, bahan pembelajaran, metodelogi pembelajaran dan penilaian pembelajaran. Dalam metodelogi pembelajaran terdiri dari dua aspek yaitu metode pembelajaran dan media pembelajaran.

Menurut Mayke (dalam Mursyad, 2015, hlm. 44) "alat permaianan edukatif (APE) adalah alat permainan yang sengaja dirancang secara khusus untuk kepentingan pendidikan.”. Adapun ciri-ciri alat permaianan edukatif menurut Mursyad (2015, hlm. 45) yaitu:

“1) Alat permainan tersebut ditujukan untuk anak PAUD, 2) Difungsikan untuk mengembangkan berbagai perkembangan anak PAUD, 3) Dapat digunakan dengan berbagai cara, bentuk dan untuk bermacam-macam tujuan aspek pengembangan atau bermanfaat multiguna, 4) Aman atau tidak berbahaya untuk anak, 5) Dirancang untuk mendorong aktivitas dan kreativitas anak, 6) Bersifat konstruktif atau ada sesuatu yang dihasilkan, 7) Mengandung nilai pendidikan."

\subsection{Karakteristik Bermain}

Menurut Piaget (dalam Sujiono, 2009, hlm. 144) mengemukakan bahwa "bermain merupakan suatu kegiatan yang dilakukan berulang-ulang dan menimbulkan kesenangan atau kepuasa bagi diri seseorang”. Hal ini sejalan dengan apa yang telah dijelaskan oleh Feed dan Therry (2015, hlm. 336) bahwa "games provide the child an alternate to fullscaleparticipation. Through games he learns an array of emotional and cognitive operations." Adapun fungsi bermain menurut Sunarti dan Purwani (2016, hlm. 16) "kegiatan bermain berfungsi meningkatkan kematangan berbagai fungsi organ tubuh, memenuhi perkembangan motorik, kogntif, sosial emosional dan kepribadian anak". Hal ini sejalan dengan yang dijelaskan oleh Gillen (2003, hlm. 31) "play is recognised as one of the most important contexts...." Elkonin (dalam Sujiono, 2009, hlm. 145) menggambarkan empat prinsip bermain yaitu:

a. Bermain dapat mengembangkan dan memahami apa yang sedang terjadi 
b. Bermain dapat memahami aturanaturan serta beradu pendapat mengenai aturan bermain

c. Anak dapat berimajinasi mengganti objek nyata dengan replika serta berpikir abstrak

d. Ketika anak mulai bermain maka ia akan berhati-hati untuk mengikuti aturan permainan yang telah ditentukan bersama teman mainnya, hal ini yang akan mengembangkan aspek esmosional anak.

Menurut Supendi dan Nurhidayat (2016, hlm. 12) terdapat beberapa alasan mengapa permainan dibutuhkan sebagai media pembelajaran, beberapa alasan tersebut dianataranya yaitu anak-anak membutuhkan pengalaman yang kaya, bermakna dan menarik, anak-anak senang pada sesuatu yang baru serta hal baru yang menantang, memungkinkan banyak indera yang terlibat seperti audio visual dan kinestetik, memungkinkan anak untuk belajar dan permainan merupakan kegiatan yang menyenangkan bagi anak.

\subsection{Pengertian Play Dough}

Play dalam bahasa inggris yang diartikan sebagai bermain dan dough dalam bahasa inggris diartikan sebagai adonan maka play dough dapat diartikan sebagai bermainan adonan. Swartz (dalam Beaty, 2015, hlm. 253) adonan mainan memunginkan anak-anak melatih kemampuan motorik halus. Anak-anak menggunakan tangan dan peralatan untuk menumbuk, menekan, membentuk, meratakan, menggulung, dan memotong. Lewat pengalaman tersebut, anak-anak mengembangkan koordinasi mata tangan yang terkontrol, ketangkasan dan kekuatan, kemampuan penting yang mereka akan butuhkan kelak untuk menulis, menggambar dan tujuan lain. Menurut Beaty (2015, hlm. 254) adapun bahan-bahan yang digunakan untuk membuat adonan mainan yaitu: "2 $1 / 2$ cangkir tepung, $1 / 2$ cangkir garam, 2 sendok teh tawas, 2 sendok makan minyak goreng, 2 cangkir air dan pewarna makanan".

\section{METODE}

\subsection{Teknik Pegumpulan Data}

Teknik pengumpulan data dalam penelitian ini dilakukan dengan tiga teknik yaitu:

\section{Observasi}

Observasi merupakan pengamatan dengan menggunakan indera penglihatan dan tidak mengajukan pertanyaan-pertanyaan dalam penelitian ini. Teknik observasi ini mencakup instrumen:

a. Lembar rencana pelaksanaan pembelajaran

Lembar ini mencakup Rencana Pelaksanaan Pembelajaran Harian (RPPH) dan skenario kegiatan, lembar ini merupakan salah satu tolak ukur akan perencanaan pembelajaran.

b. Lembar penilaian kemampuan guru

Alat penilaian kemampuan guru (APKG) terbagi menjadi dua yaitu alat penilaian kemampuan guru khusus yaitu alat penilaian kemampuan guru dalam pembelajaran menggunakan play dough dan alat penilaian kemampuan guru umum yaitu alat penilaian kemampuan guru dalam merencanakan dan melaksanakan pembelajaran. Lembar ini merupakan salah satu tolak ukur akan keberhasilan kegiatan pembelajaran.

c. Lembar pengamatan anak

Peningkatan kemampuan motorik halus anak dapat di ukur atau dilihat dari lembar pengamatan ini, aktifitas belajar yang menyangkut motorik halus anak dapat terperinci secara akurat.

d. Lembar catatan lapangan

Lemabar ini berisikan tentang kejadiankejadian yang tidak biasanya dilakukan oleh anak yang berhubungan dengan penelitian.

2. Wawancara

Subjek pada teknik ini yaitu guru. Wawancara dilakukan dalam rangka mengetahui kondisi kemampuan guru dan siswa, kegiatan pembelajaran yang biasa dilakukan serta kesulitan guru dalam mengatasi hambatan yang terjadi dalam kelas.

3. Dokumentasi

Dokumentasi dilakukan selama kegiatan pembelajaran dengan menggunakan Play 
Dough untuk meningkatkan kemampuan motorik halus anak.

\subsection{Teknik Analisis Data}

Menurut Asip dan Hidayat (2015 hlm.

105) "teknik analisis data merupakan cara yang digunakan untuk mengolah data yang didapatkan dari lapangan." Teknik analisis data pada penelitian ini menggunakan teknik analisis data kualitatif dan teknik analis data kuantitatif.

\section{Teknik analisis data kualitatif}

Teknik analisis data kualitatif dilakukan dengan mengenalisa kejadian saat berlangsungnya penelitian, hal ini dilakukan secara terus menerus sampai menemukan data jenuh. Dalam teknik analisis data kualitatif dilakukan dengan melalui tiga tahapan yaitu:

\section{a. Reduksi data}

Reduksi data merupakan kegiatan memfokuskan perhatian pada penyederhanaan data dengan cara menyeleksi dan mengelompokan data pada hal-hal yang penting yang berkaitan dengan variabel penelitian. Dengan demikian data yang telah di reduksi memberikan gambaran yang jelas tentang penelitian kemudian reduksi data dilakuakan bersamaan dengan pengambilan data.

b. Penyajian data

Hasil reduksi data yang diperoleh selanjutnya ditulis dalam bentuk narasi singkat dan sistematis. Penyajian data ini dilakukan untuk mempermudah dalam pengambilan kesimpulan. Pada peneltian tindakan kelas ini, penyajian data ditulis dalam catatan lapangan penelitian.

\section{c. Penarikan kesimpulan}

Pada penarikan kesimpulan perlu didukung dengan bukti-bukti yang valid. Bukti tersebut diambil dari hasil penyajian data yang telah dilakukan sebelumnya.

\section{Teknik analis kualitatif}

Data hasil observasi kemampuan guru dan anak yang telah terkumpul pada setiap siklus dianalisis menggunakan statistik deskriptif. Prosedur dan pengolahan data pada penelitian ini dapat dijelaskan sebagai berikut:

a. Pengumpulan, pengkodean dan pengkatagorian data
Pada tahap ini peneliti mengumpulkan seluruh data yang diperoleh berdasarkan instrumen penelitian. Setelah itu data diberi kode dan dikategorikan berdasarkan jenisnya. Pada penelitian ini data dikategorikan berdasrkan fokus tindakan dan berdasarkan objek yang diamati.

b. Verifikasi data

Untuk memperoleh data yang valid, hasil pengkategorian data diverifikasi. Teknik verifikasi data yang digunakan pada penelitian ini yaitu:

1) Triangulasi

Triangulasi data merupakan pemeriksaan kebenaran data pada hasil penelitian dengan beberapa pihak yang bersangkutan. Kegiatan triangulasi pada penelitian tindakann kelas ini dilakukan melalui kegiatan refleksi antara peneliti dengan guru mitra yaitu Ibu Nenden Sumiati.

2) Interpretasi

Interpretasi dilakukan untuk menafsirkan keseluruhan data yang diperoleh dari hasil penelitian. Penafsiran data selanjutnya akan digunakan untuk mengetahui peningkatan kemampuan guru dan anak dalam pembelajaran. Peningkatan kemampuan guru dan anak dilihat dari perbandingan persentase kemampuan yang telah dicapai. Adapun rumus yang digunakan untuk menghitung persentase dalam penelitian ini yaitu: (Purwanto, 2008, hlm. 102)

$$
\mathrm{NP}=\mathrm{R}: \mathrm{SM} \times 100
$$

\section{Keterangan:}

NP : nilai persen yang dicari atau diharapkan

R : skor mentah yang diperoleh anak

SM : skor maksimum ideal dari tes yang bersangkutan

100 : bilangan tetap

RR : rata-rata

Selanjutnya data hasil perhitungan tersebut dapat diinterpretasikan dalam lima tingkatan, yaitu: (Arikunto, 2013, hlm. 319)

a) Kriteria sangat baik, apabila memperoleh skor dengan persentase $80 \%-100 \%$ 
b) Kriteria baik, apabila memperoleh skor dengan persentase $60 \%-80 \%$

c) Kriteria cukup, apabila memperoleh skor dengan persentase $40 \%-60 \%$

d) Kriteria kurang, apabila memperoleh skor dengan persentase $20 \%-40 \%$

e) Kriteria sangat kurang, apabila memperoleh skor dengan persentase 0\%-20\%

3) Saturasi

Saturasi merupakan suatu keadaan dimana data sudah jenuh dan tidak lagi mengalami peningkatan. Dalam upaya mencapai saturasi pada penelitian tindakan kelas ini dilakukan sebanyak tiga siklus. Setiap siklus terdapat satu tindakan dalam arti satu hari.

\section{HASIL DAN PEMBAHASAN}

Berdasarkan hasil observasi pra siklus yang dilakukan pada bulan maret 2017 terdapat 9 orang anak belum berkembang dengan peresentase $45 \%$ dan 11 orang anak sudah mulai berkembang dengan persentase 55\% terdapat pada interval $40 \%-60 \%$ dengan kriteria cukup jumlah anak yang hadir yaitu sebanyak 20 orang anak. Dengan demikian dapat disimpulkan bahwa perkembangan fisik motorik dalam lingkup perkembangan motorik halus anak usia 5-6 tahun pada kelompok B TK Sejahtera 4 Kelurahan Karsamenak Kecamatan Kawalu Kota Tasikmalaya berada dalam kriteia cukup akan tetapi belum mencapai indikator ketercapaian pada penelitian ini. Berdasarkan hasil kemampuan awal tersebut maka perlu adanya suatu refleksi terhadap kemampuan anak. Refleksi yang difokuskan adalah bagaimana cara meningkatkan kemampuan fisik motorik, khususnya dalam aspek motorik halus anak. Play dalam bahasa inggris yang diartikan sebagai bermain dan dough dalam bahasa inggris diartikan sebagai adonan maka play dough dapat diartikan sebagai bermainan adonan. Swartz (dalam Beaty, 2015, hlm. 253) adonan mainan memunginkan anak-anak melatih kemampuan motorik halus. Anak-anak menggunakan tangan dan peralatan untuk menumbuk, menekan, membentuk, meratakan, menggulung, dan memotong. Lewat pengalaman tersebut, anak-anak mengembangkan koordinasi mata tangan yang terkontrol, ketangkasan dan kekuatan, kemampuan penting yang mereka akan butuhkan kelak untuk menulis, menggambar dan tujuan lain. Dengan demikian peneliti tertarik untuk menggunakan play dough sebagai upaya untuk meningkatkan kemampuan motorik halus anak.

Pada siklus I tanggal 18 april 2017 dengan tema negaraku sub tema wakil presiden kemampuan motorik halus anak terdapat 4 orang anak belum berkembang dengan persentase $20 \% 11$ orang anak mulai berkembang dengan persentase $80 \%$ jumlah anak yang hadir yaitu sebanyak 20 orang anak dengan total skor keseluruhan 222 rata-rata keseluruhan 1,82 dengan persentase keseluruhan $46 \%$ terdapat pada interval $40 \%$ $60 \%$ dengan kriteria cukup, kemampuan guru dalam pembelajaran menggunakan play dough mendapat total skor 23 rata-rata 2,3 dengan persentase keseluruhan $57,5 \%$ terdapat pada interval 40\%-60\% dengan kriteria cukup, kemampuan guru dalam merencanakan pembelajaran mendapat total skor 32 rata-rata 2,3 dengan persentase keseluruhan $57,1 \%$ terdapat pada interval $40 \%-60 \%$ dengan kriteria cukup dan kemampuan guru dalam melaksanakan pembelajaran mendapat total skor 53 rata-rata 2,1 dengan persentase keseluruhan 53\% terdapat pada interval 40\%$60 \%$ dengan kriteria cukup. Akan tetapi belum mencapai indikator ketercapaian pada penelitian ini maka perlu dilakukannya refleksi pada siklus II.

Pada siklus II yang dilakukan tanggal 25 april 2017 dengan tema alam semesta sub tema bumi kemampuan motorik halus anak terdapat 9 orang anak mulai berkembang dengan persentase $53 \% 8$ orang berkembang sesuai harapan dengan persentase $47 \%$ jumlah anak yang hadir yaitu sebanyak 17 orang anak dengan total skor keseluruhan 259 rata-rata keseluruhan 2,5 dengan persentase keseluruhan $63 \%$ terdapat pada interval $60 \%-80 \%$ dengan kriteria baik, kemampuan guru dalam pembelajaran menggunakan play dough mendapat total skor 29 rata-rata 2,9 dengan 
persentase keseluruhan $72,5 \%$ terdapat pada interval $60 \%-80 \%$ dengan kriteria baik, kemampuan guru dalam merencanakan pembelajaran mendapat total skor 41 rata-rata 2,9 dengan persentase keseluruhan 73,2\% terdapat pada interval $60 \%-80 \%$ dengan kriteria baik dan kemampuan guru dalam melaksanakan pembelajaran mendapat total skor 73 rata-rata 2,9 dengan persentase keseluruhan $73 \%$ terdapat pada interval $60 \%$ $80 \%$ dengan kriteria baik. Akan tetapi belum mencapai indikator ketercapaian pada penelitian ini maka perlu dilakukannya refleksi pada siklus III.

Pada siklus III yang dilakukan tanggal 03 mei 2017 dengan tema alam semesta sub tema benda langit sub-sub tema bulan kemampuan motorik halus anak terdapat 13 orang anak berkembang sesuai harapan dengan persetase $76 \% 4$ orang anak berkembang sangat baik dengan persentase $24 \%$ jumlah anak yang hadir yaitu sebanyak 17 orang anak dengan total skor keseluruhan 343 rata-rata keseluruhan 3,4 dengan persentase keseluruhan $84 \%$ terdapat pada interval $80 \%$ $100 \%$ dengan kriteria sanagat baik, kemampuan guru dalam pembelajaran menggunakan play dough mendapat total skor 34 rata-rata 3,4 dengan persentase keseluruhan $85 \%$ terdapat pada interval $80 \%-100 \%$ dengan kriteria sangat baik, kemampuan guru dalam merencanakan pembelajaran mendapat total skor 48 rata-rata 3,4 dengan persentase keseluruhan $85,7 \%$ terdapat pada interval $80 \%$ $100 \%$ dengan kriteria sangat baik dan kemampuan guru dalam melaksanakan pembelajaran mendapat total skor 85 rata-rata 3,4 dengan persentase keseluruhan $85 \%$ terdapat pada interval $80 \%-100 \%$ dengan kriteria sangat baik. Pada siklus III kemampuan motorik halus anak sudah mencapai indikator ketercapaian pada penelitian ini sehingga tindakan dirasa cukup.

Dengan demikian dapat disimpulkan bahwa melalui penggunaan play dough dapat meningkatkan kemampuan fisik motorik dalam lingkup perkembangan motorik halus anak usia 5-6 tahun pada kelompok B TK Sejahtera 4
Kelurahan Karsamenak Kecamatan Kawalu Kota Tasikmalaya.

\section{KESIMPULAN}

Berdasarkan hasil penelitian dan pembahasan mengenai peningkatan kemampuan motorik halus anak usia 5-6 tahun melalui penggunaan play dough yang merupakan penelitian tindakan kelas pada kelompok B TK Sejahtera 4 kelurahan karsamenak kecamatan kawalu kota tasikmalaya tahun pelajaran 2016-2017, maka dapat diperolah simpulan sebagai berikut:

1. Kemampuan guru dalam merancang Rencana Pelaksanaan Pembelajaran Harian (RPPH) melalui penggunaan play dough untuk meningkatkan kemampuan motorik halus anak usia 5-6 tahun pada kelompok B TK Sejahtera 4 kelurahan karsamenak kecamatan kawalu kota tasikmalaya tahun pelajaran 2016-2017, dengan memperhatikan petunjuk Penelitian Tindakan Kelas (PTK) yang diberlakukan dan refleksi dari setiap siklus pembelajaran dapat meningkatkan kemampuan motorik halus anak usia 5-6 tahun pada kelompok B di TK Sejahtera 4 kelurahan karsamenak kecamatan kawalu kota tasikmalaya tahun pelajaran 2016-2017. Hal tersebut dibuktikan dalam peningkatan kemampuan guru dalam merancang Rencana Pelaksanaan Pembelajaran Harian (RPPH) pada tiap siklus. Siklus I sebesar $57,1 \%$, siklus II 73,2\%, dan siklus III $85 \%$.

2. Kemampuan guru dalam melaksanakan pembelajaran dengan menggunakan play dough untuk meningkatkan kemampuan motorik halus anak ternyata dapat meningkatkan kemampuan guru dalam kegiatan pembelajaran tentang kemampuan motorik halus anak usia 5-6 tahun pada kelompok B di TK Sejahtera 4 kelurahan karsamenak kecamatan kawalu kota tasikmalaya tahun pelajaran 2016-2017. Hal ini dapat dibuktikan dengan meningkatnya kemampuan guru dalam mengelola pembelajaran pada setiap siklusnya. Siklus I sebesar 53\%, siklus II 73\% dan siklus III $85,7 \%$. Sedangkan kemampuan guru dalam 
menggunakan play dough mengalami peningkatan pula. Hal ini dibuktikan oleh peningkatan kemampuan guru dalam menggunakan play dough pada setiap siklusnya. Siklus I sebesar 57,5\%, siklus II $72,5 \%$ dan siklus III $85 \%$.

3. Kemampuan motorik halus anak usia usia 5-6 tahun pada kelompok B TK Sejahtera 4 kelurahan karsamenak kecamatan kawalu kota tasikmalaya tahun pelajaran 20162017 melalui penggunaan play dough mengalami peningkatan. Hal ini dibuktikan dengan meningkatnya kemampuan anak pada tiap indikator yang telah ditentukan di setiap siklusnya. Berdasarkan kemampuan motorik halus anak pada siklus I terdapat 4 orang anak belum berkembang dan 16 orang anak mulai berkembang dengan persentase keseluruhan siklus I sebesar $46 \%$ serta jumlah anak yang hadir sebanyak 20 orang anak, pada siklus II terdapat 9 orang anak mulai berkembang dan 8 orang anak berkembang sesuai harapan dengan persentase keseluruhan $63 \%$ serta jumlah anak yang hadir sebanyak 17 orang anak dan siklus III terdapat 13 orang anak berkembang sesuai harapan dan 4 orang anak berkembang sangat baik dengan persentase keseluruhan $84 \%$ serta jumlah anak yang hadir sebanyak 17 orang anak.

\section{SARAN}

Berdasarkan simpulan yang telah dipaparkan terdapat beberapa hal yang menjadi catatan sebagai saran, diantaranya yaitu:

1. Bagi guru

a. Guru sebaiknya dapat mengembangkan inovasi berbagai metode, model, strategi dan penggunaan bahan ajar agar lebih menarik dan menyenangkan sehingga anak termotivasi, antusias, kreatif, aktif dan produktif dalam mengikuti pembelajaran khususnya dalam meningkatkan kemampuan motorik halus.

b. Guru hendaknya dapat menyajikan pembelajaran melalui permainan yang menarik, baru dan menyenangkan bagi anak tentunya hal ini disesuaikan dengan tahap perkambangan anak dan kompetensi yang diharapkan.

c. Menjadikan play dough sebagai salah satu alternatif penggunaan bahan ajar terutama untuk meningkatkan kemampuan motorik halus anak.

2. Bagi lembaga pendidikan anak usia dini

a. Memberikan kesempatan guru untuk menentukan metode, model, strategi dan penggunaan bahan ajar apa yang tepat dalam meningkatkan kemampuan motorik halus.

b. Menjadikan play dough sebagai salah satu penggunaan bahan ajar untuk meningkatkan kemampuan motorik halus.

c. Memfasilitasi perkembangan kemampuan motorik halus anak melalui penyediaan bahan ajar yang dapat memotivasi guru maupun anak untuk menciptakan suatu pembelajaran yang menyenangkan sehingga dapat meningkatkan kualitas pendidikan khususnya pendidikan anak usia dini.

\section{DAFTAR PUSTAKA}

Arikunto, Suharsimi. (2013). Prosedur Penelitian. Jakarta: Rineka Cipta.

Asip dan Hidayat, Syarif. (2015). Penelitian Tindakan Kelas. Jakarta: Pustaka Mandiri.

Beaty. (2015). Observasi Perkembangan Anak Usia Dini. Jakarta: Kencana Prenamedia Goup.

Dimyati. (2013). Metode penelitian pendidikan \& aplikasinya pada pendidikan anak usia dini (PAUD). Jakarta: Kencana Prenadamedia Group.

Fred, L. \& Therry, N. (1971) The games children play. Childhood Education, 47 (6), hlm. 335-338.

Gillen, J. (2003). The language off children. London: Routledge.

Guddemi, M. (1990). Play and learning for the spesial child. Early Education for the Handicapped, 18 (2), hlm. 39-40.

Hoerr, T.R dkk.(2010). Celebrating Every Learning. San Francisco: Jossey Bass.

Iskandar, Beny. (2005). Pengembangan Motorik Anak Usia Pra Sekolah. Bandung: PPG Tertulis Bandung. 
Kurtz, L.A. (2008), Understanding Motor Skills In Children With Dyspraxia, Adhd, Autism Other Learning Disabilities. London: Jessica Kingsley Publishers london and philadelphia.

Mudjito. (2007). Pedoman Pembelajaran Bidang Pengembangan Fisik/Motorik Di Taman Kanak-Kanak. Jakarta: Departemen Pendidikan Nasional Direktorat Jendral Managemen Pendidikan Dasar dan Menengah Direktorat Pembinaan Taman Kanak-kanak dan Sekolah Dasar.

Mukhtar dkk. (2013). Orientasi Baru Pendidikan Anak Usia Dini. Jakarta: Kencana Prenadamedia Group.

Mulyasa. (2013). Praktik Penelitian Tindakan

Kelas. Bandung: PT Remaja Rosdakarya.

Mursyid (2015). Pengembangan Pembelajaran

Paud. Bandung: PT Remaja Rosdakarya.

Peraturan Menteri Pendidikan dan Kebudayaan Republik Indonesia Nomor 137 Tahun 2014 tentan Standar Nasional Pendidikan Anak Usia Dini.

Peraturan Meteri Pendidikan dan Kebudayaan Republik Indonesia Nomor 146 Tahun 2014 tentang Kurikulum 2013 Pendidikan Anak Usia Dini.

Purwato, N. (2008). Prinsip-Prinsip Dan Teknik Evaluasi Pengajaran. Bandung: Remaja Rosda Karya.

Rahyubi, Heri. (2011). Teori-teori Belajar Dan Aplikasi Pembelajaran Motorik. Desember: Referens.

Indrati, Yuke dkk. (2014). Buku Panduan Pendidikan Kurikulum 2013 Paud Anak Usia 5-6 Tahun. Jakarta: Pusat Kurikulum dan Pembukuan, Badan Penelitian dan Pengembangan Kementerian Pendidikan dan Kebudayaan.

Suciati dkk, (2016). Pendidikan Anak Usia Dini Universitas Pendidikan Ganesha. Pengaruh Kegiatan Finger Painting Berbasis Teori Lokomosi Terhadap Keterampilan Motorik Halus Anak. 4. (2), hlm 1-12.

Sugiyanto, (2002). Perkembangan Dan Belajar Motorik. Jakarta: Pusat Penerbitan Universitas Terbuka.
Sujiono. (2009). Konsep Dasar Pendidikan Anak Usia Dini. Jakarta: PT Indeks.

Sunarti. Euis, Rulli Purwan. (2016). Ajarkan Anak Keterampilan Hidup Sejak Dini. Bogor: Bestari.

Supendi, Pepen dan Nurhidayat. (2016). 50 Permainan Indoor Dan Out Door Mengasyikkan. Jakarta: Penebar Plus.

Trianto. 2011. Pedoman Lengkap Penelitian Tindakan Kelas. Jakarta: Prestasi Pustakaraya. Umama. (2016). Pojok Bermain Anak. Yogyakarta: Stiletto Book.

Wiratni dkk. (2016). Pendidikan Anak Usia

Dini Universitas Pendidikan Ganesha. Penerapan Kegiatan Finger Painting Untuk Meningkatkan Perkembangan Motorik Halus Anak Kelompok B2 TK Dharma Praja Denpasar. 4 (2), hlm 1-11.

Wiyani. (2014). Psikologi Perkembangan Anak Usia Dini. Yogyakarta: Gava Media.

Yus,Anita. (2010). Penilaian Perkembangan Belajar Anak Taman Kanak-Kanak. Jakarta: Kencana Prenada Media Group. 